\title{
Essential Oil Composition and Cytotoxic Activity of Libanotis transcaucasica Schischk. from Iran
}

\author{
Sara Shahabipour ${ }^{1}$, Omidreza Firuzi ${ }^{1}$, Mojtaba Asadollahi ${ }^{1}$, Mohammad Miri ${ }^{1}$ and Katayoun Javidnia ${ }^{1,2 *}$ \\ ${ }^{1}$ Medicinal \& Natural Product Chemistry Research Centre, Shiraz University of Medical Sciences, Shiraz, Iran \\ ${ }^{2}$ Department of Medicinal Chemistry, Faculty of Pharmacy, Shiraz University of Medical Sciences, Shiraz, Iran
}

\begin{abstract}
Background: Libanotis transcaucasica Schischk. belonging to the family of Apiaceae is a perennial plant that is distributed in Europe, northwest of Iran and also Caucasia.

Purpose: Due to the interest on development of drugs from natural origins, we studied the components and cytotoxic activity of essential oil from $L$. transcaucasica.

Methods: The essential oil of $L$. transcaucasica was obtained by hydro distillation of its air-dried aerial parts and was analyzed by gas chromatography (GC-FID) and gas chromatography-mass spectrometry (GC-MS). Cytotoxic activity of the essential oil was assessed on four human cancer cell lines (HeLa, LS180, MCF-7 and Raji).

Results: The yield of oil was $0.9 \%(\mathrm{w} / \mathrm{w})$ and it had yellow color. Fifty-four compounds in L. transcaucasica representing $84.0 \%$ of the oil components were identified. Germacrene B $(20.2 \%)$ was the most abundant compound in this oil, followed by isospathulenol $(11.0 \%)$, germacrene $D(9.2 \%)$ and kessane $(5.5 \%)$. The volatile oil displayed weak to moderate cytotoxic activity in all evaluated human cancer cell lines $\left(I C_{50}=0.9-0.2 \mathrm{mg} / \mathrm{ml}\right)$. The highest and the lowest cytotoxic effects were observed on Raji and LS180 cell lines, respectively.
\end{abstract}

Conclusion: Sesquiterpene hydrocarbons were identified as the main components of the essential oil (48.3\%). The cytotoxic activity observed in the essential oil may be contributed to the existence of this group of hydrocarbons in the plant.

Keywords: Libanotis transcaucasica; Essential oil; Germacrene B; Cytotoxicity

\section{Introduction}

The genus Libanotis L. belongs to the family Apiaceae. This genus consists of about 60 species widespread in Europe, Africa, Asia, and Oceania. The plants of this family possess peculiar botanical characteristics such as the typical umbellate inflorescences and are distributed widely from tropical to temperate regions where they often are used as spices or drugs [1,2].

According to the ancient literature, some of the Libanotis species such as L. buchtormensis and L. laticalycina have been reported to be used as traditional medicinal plants [2]. The various species of this genus are also believed to have anti-inflammatory, antipyretic, analgesic, and spasmolytic effects [2].

L. transcaucasica is a perennial plant and distributed in Europe, northwest of Iran and also Caucasia [3,4]. Libanotis montana var. lasiopetala, seseli libanotis var. armeniacum, and seseli transcaucasicum are the other names for this plant [3,5]. Sesquiterpene hydrocarbons [4], monoterpene hydrocarbons [6] and coumarins [4,7] were isolated by previous phytochemical studies of $L$. transcaucasica.

The chemical constituents of the essential oil from L. buchtormensis have also been investigated before [2]. Previously, the compositions of different fractions of the essential oil from L. transcaucasica have been reported $[6,8]$. But to our best knowledge, there is not any published report on the analysis of phytochemical composition of the essential oil from $L$. transcaucasica by GC and GC-MS. In addition, no previous biological study has been performed on the $L$. transcaucasica essential oil. In the present work, chemical composition and cytotoxic activity of essential oil from L. transcaucasica were reported.

\section{Materials and Methods}

\section{Reagents and chemicals}

RPMI 1640, fetal bovine serum (FBS), trypsin and phosphate buffered saline (PBS) were purchased from Biosera (Ringmer, http:// www.biosera.com). Acetic acid glacial, dimethyl sulphoxide, hexane, methanol were purchased from Merck (Darmstadt, http://www.merck. de). 3-(4,5-Dimethylthiazol-2-yl)-2,5-diphenyltetrazolium bromide (MTT), was obtained from Sigma-Aldrich (St. Louis, http://www. sigma-aldrich.com). Penicillin/streptomycin and doxorubicin were purchased from EBEWE Pharma (Unterach, http://www.ebewe.at) and Invitrogen (San Diego, http://www.invitrogen.com), respectively.

\section{Plant material and isolation procedure}

The plant material was collected in June 2008 from northwestern of Iran. The plant was identified at the Department of Biology, University of Shiraz, Iran and a voucher specimen was deposited at the herbarium of the Medicinal and Natural Products Chemistry Research Center, Shiraz, Iran (No. PC 87-6). The aerial parts of collected plant were air-dried at ambient temperature in the shade and grinded to powder. The powder $(60 \mathrm{~g})$ was subjected to hydro-distillation for $4 \mathrm{~h}$ using a Clevenger type apparatus to obtain the essential oil. The oil was dried over anhydrous sodium sulfate and stored in a sealed vial at $4-6^{\circ} \mathrm{C}$ in the dark till analysis.

\section{Identification of the oil components}

Gas chromatography (GC) analysis was carried out using an

*Corresponding author: Katayoun Javidnia, Medicinal \& Natural Products Chemistry Research Centre, Shiraz University of Medical Sciences, Shiraz, Iran, Tel: 98-711-230-3872; Fax: 98-711-233-2225; E-mail: javidniak@sums.ac.ir, kjavidnia@gmail.com

Received April 08, 2013; Accepted May 22, 2013; Published May 25, 2013

Citation: Shahabipour S, Firuzi O, Asadollahi M, Miri M, Javidnia K (2013) Essentia Oil Composition and Cytotoxic Activity of Libanotis transcaucasica Schischk. from Iran. Nat Prod Chem Res 1: 108. doi:10.4172/2329-6836.1000108

Copyright: @ 2013 Shahabipour S, et al. This is an open-access article distributed under the terms of the Creative Commons Attribution License, which permits unrestricted use, distribution, and reproduction in any medium, provided the original author and source are credited. 
Agilent $6890 \mathrm{~N}$ chromatograph (FID) with an HP-5 column $(30 \mathrm{~m} \times 0.25$ $\mathrm{mm} ; 0.25 \mu \mathrm{m}$ film thickness). The oven temperature increased from 60 to $240^{\circ} \mathrm{C}$ at a rate of $3^{\circ} \mathrm{C} / \mathrm{min}$, the injector and detector temperature were $240^{\circ} \mathrm{C}$ and $250^{\circ} \mathrm{C}$, respectively. Helium was used as the carrier gas with a flow rate of $0.9 \mathrm{ml} / \mathrm{min}$. Relative percentage data were obtained from electronic integration of peak areas without the use of correction factor. GC-MS analysis of the essential oil was performed using an Agilent 7890A chromatograph operating at $70 \mathrm{eV}$ ionization energy, $0.5 \mathrm{~s} / \mathrm{scan}$ and the mass range of 35-400, equipped with a HP- 5 capillary column (phenyl methyl siloxane, $30 \times 0.25 \mathrm{~mm}^{2}, 0.25 \mu \mathrm{m}$ film thickness) programmed as above with helium as the carrier gas with the flow rate of $0.9 \mathrm{ml} / \mathrm{min}$ and a split ratio of 1:20.

Retention indices were determined by using retention times of n-alkanes that had been injected after the oil under the same chromatographic conditions according to the Van Den Dool method [9]. The compounds were identified by comparison of their mass spectra with the Wiley and Mass finder 3 libraries or with the published mass spectra [10].

\section{Cytotoxicity assay}

HeLa (human cervical adenocarcinoma), LS180 (human colon adenocarcinoma), MCF-7 (human breast adenocarcinoma) and Raji (human B lymphoma) cell lines were obtained from the National Cell Bank of Iran, Pasteur Institute, Tehran, Iran. All cell lines were maintained in RPMI 1640 supplemented with 10\% FBS, and 100 units/ml penicillin-G and $100 \mu \mathrm{g} / \mathrm{ml}$ streptomycin. Cells were grown in monolayer cultures, except for Raji cells, which were grown in suspension, at $37^{\circ} \mathrm{C}$ in humidified air containing $5 \% \mathrm{CO}_{2}$.

Cell viability following exposure to essential oils was estimated by using the MTT reduction assay [11-14]. HeLa and LS180 and cells were plated in 96-well microplates at densities of $1 \times 10^{5}$ and $2.5 \times 10^{4}$ cells/ $\mathrm{ml}$, respectively $(100 \mu \mathrm{l}$ per well). MCF-7 and Raji cells were plated at a density of $5 \times 10^{4}$ cells $/ \mathrm{ml}(100 \mu \mathrm{l}$ per well). Control wells contained no essential oil and blank wells contained only growth medium for background correction. After overnight incubation at $37^{\circ} \mathrm{C}$ to allow for cell attachment, half of the growth medium was removed and the essential oil, first diluted 10 times in DMSO, was serially diluted in RPMI and 3 different dilutions were added in duplicate. Plates with Raji cells were centrifuged before this procedure. Maximum concentration of DMSO in the wells was kept below $0.5 \%$. Cells were further incubated for $72 \mathrm{hr}$, except for HeLa cells, which were incubated for $96 \mathrm{hr}$. At the end of the incubation time, the medium was removed and MTT was added to each well at a final concentration of $0.5 \mathrm{mg} / \mathrm{ml}$ and plates were incubated for another $4 \mathrm{hr}$ at $37^{\circ} \mathrm{C}$. The formazan crystals, which were formed by the action of dehydrogenase enzyme in the mitochondria of viable cells, were solubilized in $200 \mu \mathrm{l}$ DMSO. The optical density was measured at $570 \mathrm{~nm}$ with background correction at $655 \mathrm{~nm}$ using a Bio-Rad microplate reader (Model 680). The percentage of inhibition of viability compared to control wells was calculated and $\mathrm{IC}_{50}$ values were calculated with the software Curve Expert version 1.34 for Windows. Each experiment was repeated 4 times and data were presented as mean \pm S.D.

\section{Results and Discussion}

The chemical composition of the essential oil of L. transcaucasica analyzed by GC and GC-MS techniques was reported. The obtained essential oil had a yellow color (yield; $0.9 \% \mathrm{w} / \mathrm{w}$ ). The GC-MS analysis of the essential oil resulted in 54 compounds, making up $84 \%$ of the total composition. According to Table 1, germacrene B (20.2\%) was the most abundant constituent in this oil, followed by isospathulenol (11.0\%), germacrene D (9.2\%), kessane (5.5\%) and sabinene $(3.8 \%)$ (Table 1).

The volatile oil of $L$. transcaucasica contained 17 sesquiterpene hydrocarbons (48.3\%), 11 oxygenated sesquiterpenes (22.7\%), 13 monoterpene hydrocarbons (10.5\%) and 10 oxygenated monoterpenes (2.2\%). The main abundant component for L. transcaucasica was Germacrene B, which was in accordance with the previous report on other Libanotis species such as L. buchtormensis. As a rich source of Germacrene B, the plant genus can also be used as flavoring agent in the food and perfume industries [2]. Sesquiterpene hydrocarbons were also reported as one of the main constituent of the essential oils from other Libanotis species $[2,15]$.

\begin{tabular}{|c|c|c|c|c|c|}
\hline Compound & RI & $(\%)$ & Compound & RI & $(\%)$ \\
\hline Octane & 800 & 0.2 & Methyl eugenol & 1403 & tr \\
\hline (2E)-Hexenal & 885 & 0.1 & $\beta$-Caryophyllene & 1419 & 0.9 \\
\hline a-Thujene & 930 & 0.1 & Y-Elemene & 1436 & 3.3 \\
\hline a-Pinene & 939 & 2.0 & a-Humulene & 1454 & 0.5 \\
\hline Sabinene & 975 & 3.8 & (E)- $\beta$-Farnesene & 1456 & 0.5 \\
\hline$\beta$-Pinene & 979 & 0.5 & Y-Muurolene & 1479 & 1.4 \\
\hline Myrcene & 990 & 1.1 & Germacrene D & 1485 & 9.2 \\
\hline a-Phellandrene & 1002 & $\operatorname{tr}$ & $\beta$-Selinene & 1490 & 3.0 \\
\hline a-Terpinene & 1017 & $\operatorname{tr}$ & a-selinene & 1498 & 1.7 \\
\hline p-Cymene & 1024 & 0.8 & $\begin{array}{l}\text { 4-epi-cis- } \\
\text { Dihydroagarofuran }\end{array}$ & 1499 & 0.4 \\
\hline Limonene & 1029 & 0.8 & Germacrene A & 1509 & 1.6 \\
\hline (Z)- $\beta$-Ocimene & 1037 & 0.6 & Cadinene- $\delta$ & 1523 & 0.6 \\
\hline (E)- $\beta$-Ocimene & 1050 & 0.3 & Kessane & 1530 & 5.5 \\
\hline Y-Terpinene & 1059 & 0.5 & Germacrene B & 1561 & 20.2 \\
\hline cis-Sabinene hydrate & 1070 & 0.1 & Mintoxide & 1565 & 0.6 \\
\hline Terpinolene & 1088 & $\operatorname{tr}$ & Spathulenol & 1578 & 0.9 \\
\hline Linalool & 1096 & 0.3 & Caryophyllene oxide & 1583 & 0.7 \\
\hline trans-Pinocamphone & 1162 & 0.3 & Copaen-4- $\alpha-$ ol- $\beta$ & 1590 & 0.3 \\
\hline Terpinen-4-ol & 1177 & 0.5 & Salvial-4(14)-en-1-one & 1594 & 1.2 \\
\hline$\alpha$-Terpineol & 1188 & $\operatorname{tr}$ & Isospathulenol & 1630 & 11.0 \\
\hline Myrtenol & 1195 & $\operatorname{tr}$ & Porosadienol & 1640 & 0.4 \\
\hline Isobornyl acetate & 1285 & $\operatorname{tr}$ & 3-iso-thujopsanone & 1643 & 0.6 \\
\hline Thymol & 1290 & 0.6 & Acorenone B & 1682 & 1.1 \\
\hline Dihydroedulan & 1290 & $\operatorname{tr}$ & $\begin{array}{l}\text { Sesquiterpene } \\
\text { hydrocarbons }\end{array}$ & - & 48.3 \\
\hline Carvacrol & 1299 & 0.4 & $\begin{array}{l}\text { Oxygenated } \\
\text { sesquiterpenes }\end{array}$ & - & 22.7 \\
\hline Bicycloelemene & 1336 & 1.1 & $\begin{array}{l}\text { Monoterpene } \\
\text { hydrocarbons }\end{array}$ & - & 10.5 \\
\hline$\delta$-Elemene & 1338 & $\operatorname{tr}$ & $\begin{array}{l}\text { Oxygenated } \\
\text { monoterpenes }\end{array}$ & - & 2.2 \\
\hline a-Copaene & 1376 & 0.6 & Other hydrocarbons & - & 0.2 \\
\hline$\beta$-Cubebene & 1388 & 0.2 & Aliphatic aldehydes & - & 0.1 \\
\hline Bourbonene- $\beta$ & 1388 & 0.4 & Total identified (\% & - & 84.0 \\
\hline$\beta$-Elemene & 1390 & 3.1 & & & \\
\hline
\end{tabular}

tr.: trace $(<0.1 \%)$. RI: retention indices relative to $\mathrm{C}_{8}-\mathrm{C}_{28} n$-alkanes on HP-5 column The components are listed in order of elution from the HP-5 column. Percentage calculated from FID data.

Table 1: The chemical composition of the essential oil from $L$. transcaucasica.

\begin{tabular}{|l|c|c|c|c|}
\hline \multirow{2}{*}{ Essential oil } & \multicolumn{4}{|c|}{$\mathrm{IC}_{50}(\mu \mathrm{g} / \mathrm{mL})$} \\
\cline { 2 - 5 } & HeLa cells & LS180 cells & MCF-7 cells & Raji cells \\
\hline L. transcaucasica & $360 \pm 63.6$ & $804 \pm 39.3$ & $587.5 \pm 62.8$ & $205 \pm 33.33$ \\
\hline Cisplatin & $5.2 \pm 1.2$ & $4.6 \pm 4.1$ & $4.6 \pm 2.9$ & $3.3 \pm 0.7$ \\
\hline
\end{tabular}

Values represent the mean of 4 experiments \pm S.D.

Table 2: In vitro cytotoxic activity of essential oil from L. transcaucasica. 
The in vitro cytotoxic activities of the essential oil from $L$. transcaucasica were shown in Table $2, L$. transcaucasica exhibited weak to moderate cytotoxic activity in the human cancer cell lines (Table 2).

As shown in Table 2, the most significant activity was observed against Raji cell lines and the lowest effect was observed on LS180 cell lines. The cytotoxic activity reported in the oil could also be contributed to the existence of some sesquiterpene hydrocarbons such as Germacrene B and Germacrene D [16,17].

\section{References}

1. Judd WS, Campbell CS, Kellogg EA, Stevens PF (1999) Plant Systematics: A Phylogenetic Approach. Publishers Sunderland, Massachusetts, USA.

2. Liang B, Li BL, Ma FJ, Yang ZJ, Dou LF (2007) Essential Oil Composition of Libanotis buchtormensis from Taibai Mountain in China. Chemistry of Natural Compounds 44: 730-732.

3. Rechinger KH (1982) Apiaceae. In Flora Iranica. Graz: Akademische Druck-u. Verlagsanstalt.

4. Prokopenko AP (1965) Libanotin: A new furocoumarin from Libanotis transcaucasica schischk. Chemistry of Natural Compounds 1: 165-168.

5. Mozaffarian V (1996) A Dictionary of Iranian Plant Names: Latin - English Persian.

6. Borovkov AV, Petov GM (1967) Composition of the essential oils of Libanotis transcaucasica. V. Chemistry of Natural Compounds 3: 196-197.

7. Turabelidze DG, Nikonov GK, Kemertelidze EP (1974) Coumarins of the roots of Libanotis transcaucasica. Chemistry of Natural Compounds 10: 405.

8. Pigulevskii GV, Bakina LA (1968) Oxygen-containing fractions of the essential oil of Libanotis transcaucasica. II. Chemistry of Natural Compounds 4: 113
9. Van Den Dool H, Kratz PD (1963) A generalization of the retention index system including linear temperature programmed gas-liquid partition chromatography. J Chromatogr 11: 463-471.

10. O. David Sparkman (1997) Identification of Essential oil Components by Gas Chromatography- Mass Spectroscopy. Journal of the American Society for Mass Spectrometry 6: 671-672.

11. Mosmann T (1983) Rapid colorimetric assay for cellular growth and survival application to proliferation and cytotoxicity assays. J Immunol Methods 65: 5563.

12. Firuzi O, Asadollahi M, Gholami M, Javidnia K (2010) Composition and biological activities of essential oils from four Heracleum species. Food Chemistry 122: 117-122.

13. Mehdipour AR, Javidnia K, Hemmateenejad B, Amirghofran Z, Miri R (2007) Dihydropyridine derivatives to overcome atypical multidrug resistance: design, synthesis, QSAR studies, and evaluation of their cytotoxic and pharmacological activities. Chem Biol Drug Des 70: 337-346

14. Jabbar SA, Twentyman PR, Watson JV (1989) The MTT assay underestimates the growth inhibitory effects of interferons. Br J Cancer 60: 523-528.

15. Ozturk S, Ercisli A (2006) Chemical composition and in vitro antibacterial activity of Seseli libanotis. World Journal of Microbiology and Biotechnology 22: $261-265$

16. Palazzo MC, Wright HL, Agius BR, Wright BS, Moriarity DM, et al. (2009) Chemical Compositions and Biological Activities of Leaf Essential Oils of Six Species of Annonaceae from Monteverde, Costa Rica. Rec Nat Prod 3: 153160

17. El Hawary SS, Galal AE, Yousif MF, Kirollos FN (2008) GC-MS and Bioactivity of the Essential Oil of Senecio rowleyanus Jacobs. Pharmacognosy magazine 4: $273-277$. 